\title{
特集／眼科とレーザー
}

\section{眼科領域における光化学療法 Photodynamic Therapy for Ocular Diseases}

\author{
森 圭介, 米谷 新 \\ 埼玉医科大学眼科学教室 \\ T350-04 埼玉県入間郡毛呂山町毛员本郷38 \\ TEL $0492-76-1250$ FAX 0492-95-8002
}

Keisuke MORI and Shin YONEYA

Department of Ophthalmology, Saitama Medical School

38 Morohongo, Moroyama-machi, Iruma-gun, Saitama-ken, 350-04 JAPAN

\section{要 旨}

加龄性黄斑変性における脈絡膜新生血管は失明の主要病因である。現在脈絡膜新生血管に対 して認められている唯一の治療法は熱作用によるレーザー光凝固であるが, 細膜全譬の陪害に より治康による視力低下を引き起こしてしまう。一方, 光化学療法は光感受性物質の集積した 組織のみを選択的に障害しうる治潦法である。第二世代光感受性物質の一つである mono-1aspertyl chlorin e 6 (NPe 6) は，皮展過敏性は低く，長波長域にその最大吸光波長を有し， 水溶性で組織代謝が速く，光感受能が高いなどの榎れた特性を持つ。我々はNPe6の眼科臨 床への汒用のため，その最大吸光波長を発振するダイオードレーザーとそのデリバリーシステ ムを開発した。加えて，実験的脈絡膜新生血管にNPe 6 を用いた光化学療法を施行し，眽絡 膜新生血管の選択的閉塞を得ることに成功した。このことから，NPe 6 を用いた光化学㪣法 は安全にかつ有勃に加榆性黄斑变性を治療しうる可能性が示㖫された。

キーワード：脈絡膜新生血管，加粗性黄斑变性, 光化学潦法, mono-1-aspertyl chlorin e 6 , ダイオードレーザー

\begin{abstract}
Choroidal neovascularization (CNV) is a leading cause of new blindness due to agerelated macular degeneration. The currently available treatment for CNV is thermal laser photocoagulation, which causes full-thickness retinal damage and can lead to visual loss. Photodynamic therapy may offer selective targeting to tissues in which sensitizers accumulate without damaging surrounding tissues. One of the second generation sensitizer : mono-l-aspertyl chlorin e6 (NPe6) has advantages of low skin photosensitization, major absorption peak at far-red light, rapid tissue uptake/clearance with hydrophilic nature and high photosensitizing ability. We improved diode laser delivery system that emits maximum absorption peak of NPe 6 for ophthalmological application. Then, we treated experimental CNV by photodynamic therapy with NPe6
\end{abstract}


and demonstrated selective occlusion of $\mathrm{CNV}$. This encouraging result suggest that photodynamic therapy with $\mathrm{NP}$ e6 may be safe and beneficial for the treatment of agerelated macular degeneration.

Key words : choroidal neovascularization, age-related macular degeneration, photodynamic therapy, mono-l-aspertyl chlorin e6, diode laser

\section{I 眼科領域における光化学療法の臨床的背景}

欧米の成人盲の原因の一位を占めており，社会的問題 ともなっている疾患が加齢性黄斑变性症 (AMD) であ り"，これに糖尿病性網膜症が続く。我が国ではまだ䌅 尿病性網膜症による失明が多いが, 近年AMDの愯病率 は急激に増加してきており，我々が調查した統計による

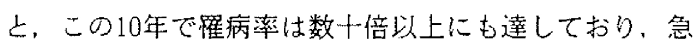
激に増加している事が日本眼科学会においても問題上 なっている。糖尿病龬膜症に対しては、レーザー光凝固 術, 硝子体手術の普及により, 相当進行した症例でも, 適切な治療を行えば，かなり高率に失明を防止すること が可能となってきている。一方，AMDでは，その発症 原因は不明であり"2，社会および環境要因など広範な背 景要因が検索されているが決め手となるものはない。唯 一，眼底の加龄性変化が大きな発症要因として挙げられ， したがって老人性円板状黄斑变性症から加龄性黄斑变性 症へ上㟝断名が代った。治療法は榶尿病と同様レーザー 光凝固 ${ }^{21}$ 之観血的治療があるが, 病変部位が視力に直接 関倸する黄斑部であり，視力の予後は不良である。これ から，高制者が增加するに従い，AMDはさらに增加す ることは想像に難くない。日本だけでなく世界的規模で AMDの有効な治療法の開発が急務であることが理解さ れる。

すでに述べたが，AMDが難治である理由は治療対象 の脈緗膜新生血管が黄斑部網膜下に好んで発生する事が 挙げられる。このため, 熱凝固作用存利用したレーザー 光凝固治療では, 新生血管だけでなく黄斑部絧膜の視細 胞も同時に障害することになり，この治療の有効でかつ 視力を保全できる上うな適疬症例は極めて限ら机ていた。 したがって，症例の多くは，視力低下を少しでも食い止 める、上いった消極的な治㾌の対象上なり，視力が保存 できる症例はごく限られている。このような状況のなか で，新生血管を観血的に切除する手術方法が開発され だ氵が，現在の所，その適応症例は視力予後の覀いもの に限られている。しかし，手術成績の検討では，眠絡膜 新生血管の除去はできても手術侵竩による網膜への障害 が強く、この手段でも視力に対しての改善効果は期待で
きない，との意見が多数を占めている。現時点では，渗 出型の加歯性黄斑症に対しての評価できる唯一の治痖法 はレーザー光疑固だけであるとの見解が示されているり。 理想的な加齢珄黄斑症の治療は, 視細胞を障害せずに脈 絡膜新生血管を閉塞菱縮させることであるということが できる。このような事情の中で期待されるのが, 光化学 物質を使用したレーザーによる選択的新生血管の閉塞で ある。この方法の有用性が確䚺され，臨床伈用されるよ うになれば、画期的治療法となることが期待される。

\section{II 加齡性黄斑変性（AMD）に対する光化 学療法の実際}

前項で記したように，従来の熱凝固効果を期待した レーザー治療では, 病変部位だけでなく、光路およびそ の周囲にある組織が熱エネルギーの伝達により障害を受 けるという問題があった（図1左）。そのため, 脈絡膜 新生血管に接する網膜は熱凝固による变性を来たし，ほ ぼ絶対暗点之なる。従って、新生血管が中心裔下にある 場合は、レーザー治療により6 段階以上の視力低下が引 き起こされてしまう。

一方, 光化学療法によれば, あらかじめ投与された光 感受性物質の集積した部位のみを選规的に障害しう るがしう利点があり，中心窝下の脈絡膜新生血管の 選択的閉塞に応用可能であることが示唆されている”。 この方法の原理は，脈絡膜新生血管に集積した光感受性 物質をレーザー光で励起し、脈絡膜新生血管のみを選択 的に障害させるという方法である(図 1 右)。この選択 的治療を完遂するための条件として，脈絡膜新生血管に 光感受性物質が集積する事，そしてその時期を同定する 事, 光感受性物質に毒性がなく体内から早期に排泄され る事, 組織透過性の点から励起光の波長は600 800 nm が望ましい事，などの点が挙げられる。

眼科領域での光化学療法としては既に第一世代の光感 受性物質であるへマトポルフィリン誘尊体の応用が悪性 腫煌に対して臨床的に8 ，脈絡膜新生血管に対しては奏 験的に”試みられている。600〜800nmの波長域でのへ マトポルフィリン誘導体の光子吸収量は弱く, 励起効率 

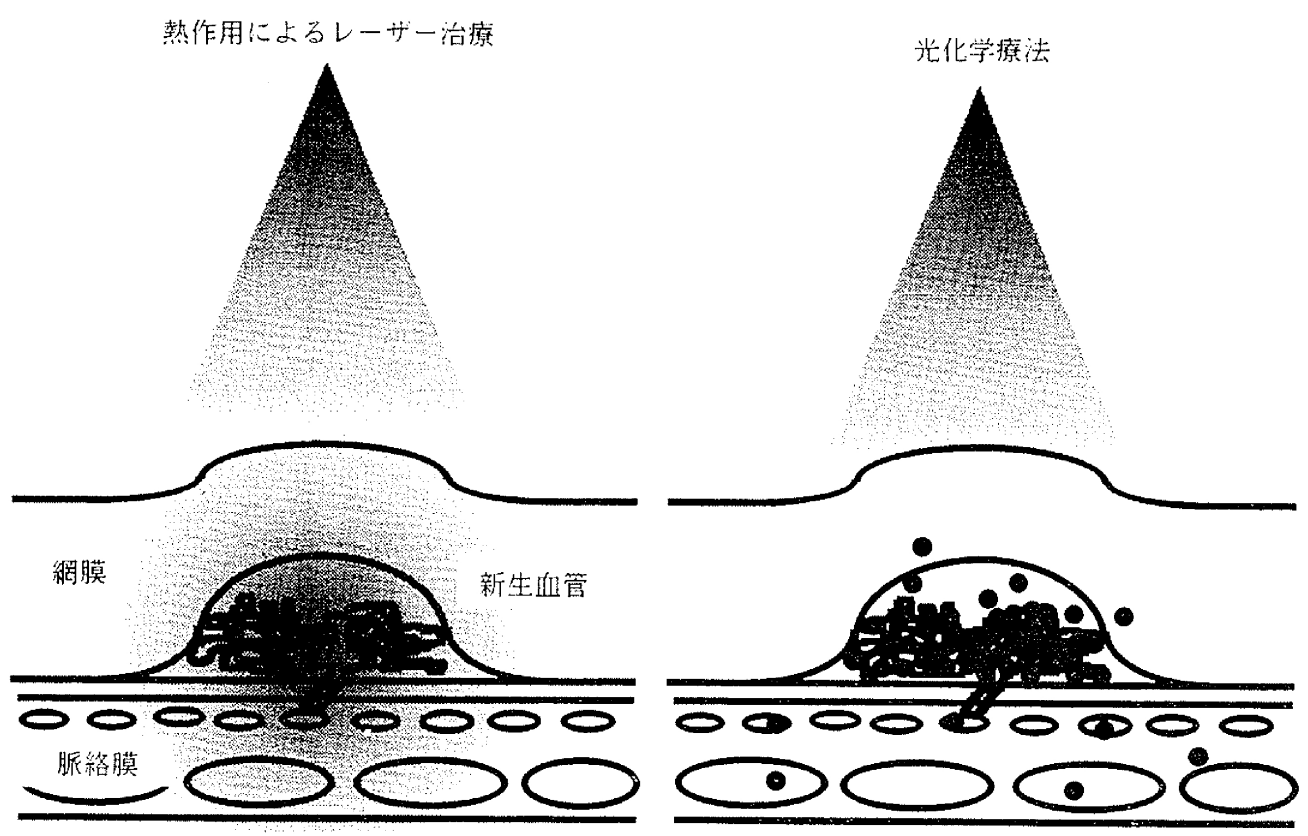

光感受性物貿

図1熱作用によるレーザー治療と光化学療法の原理

熱作用によるレーザー治療では熱エネルギーの周囲組織への伝達により障害されるのに対し， 光化学療法では光感受性物質の集積した部位を選択的に攻撃しうる。

の悪いことがその欠点として指摘されている9!。また， ヘマトポルフィリン誘梘体の他の問題点として, 体内で の代謝が遅く，光線過敏症などの全身合併症の発生が遷 延することが指摘されている9”。そのためにへマトポル フィリン誘導体を用いた光化学療法は広く臨床応用され るには至らなかった。これらのことから、全身合併症が 少なく，長波長域にその最大吸光波長を有し，より勃率 よく標的組織を障害しうる第二世代の光感受性物質が開 発された。そのうち, 眼科領域で研究されている代表的 なものとして, benzo-porphyrin derivative monoacid ring $A^{(0)}$, chloro-aluninum sulfonated phthalocya nine ${ }^{11)}$, mono-l-aspertyl chlorin e6 (NPe 6, ME 2906)などが挙げられる。このうち, 殺細胞作用の主体 とさ机ている一重項酸素12131を最も効率よく発生し, かつ，体内での代謝が最も速く，全身合併症の軽度なも のがNPe6である(3)。このNPe 6 は，水溶性であり， 血中のアルブミンやリポ蛋白と結合しやすくは，血液 柶のある脳や感覚網膜には抁散しにくいこと，また，細 胞内への移動は䆩食や細胞吸水などの能動輸送を受ける こといがその特性として挙げられている。これらの特 性から，NPe 6 は感党網膜を障害せずに，脈絡膜新生 血筸を選択的に治㾞しうることが期待される。
我々は, この NPe 6 を用いた眼科領域への応用, 特

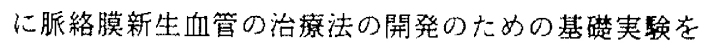
行ってきた。その詳細は既報 ${ }^{(6)-18) に ゆ す ゙ る か ゙ ， 以 下 ~}$ にその概略を記す。

実験は以下の 4 段階にわけて行った。

\section{\#1. $664 \mathrm{~nm}$ 半導体レーザーの眼科用治療装置} の開発

NPe 6 の最大吸光波長を発振する半賉体レーザーを 開発し、眼科専用のレーザーデリバリーシステムに搭载 した。このデリバリーシステムは細隙灯顕微鏡を改良し たものであり，眼底観察用にコンタクトレンズを使用す る。この装置を用いると, 眼底を直視下のも之治療を行 うことができる。エイミング光として633nmのへリウ ム・ネオンレーザーを搭載し，その照明强度はNPe 6 を励 起させないよう $80 \mu \mathrm{W}$ と低く設定した。また，眼底観察 用の照明光は $664 \mathrm{~nm}$ 近傍の光をフィルターを用いて カットし、やはり安全に治療が行えるようにした（図2)。 加えて、レーザー光束内の光エネルギー分布が均一にな るパーフォーカルシステムを採用し，光ムラによる治㞠 効果のばらつきが生じないようにした（図 3)。

\section{\#2. 電子スピン共鳴法 (ESR) による検討}

上記のレーザー装置で効率よくNPe 6 が励起される 
比透過譬

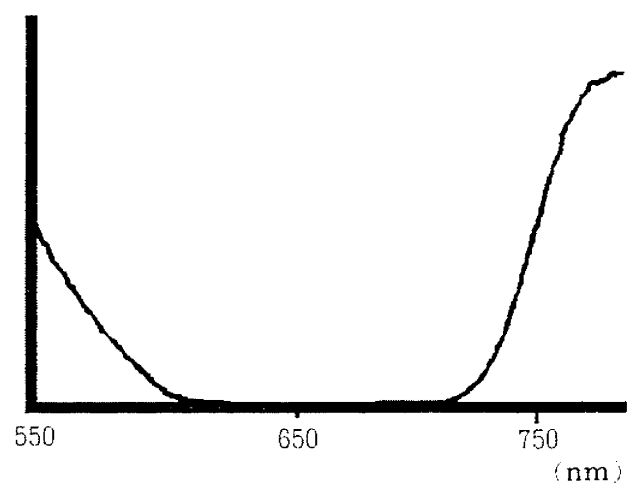

図 2 Laser Delivery Systemの照明光の波長分布特性 照明光でNPe 6 が励起されないよう $664 \mathrm{~nm} の$ 近傍の光を除去。
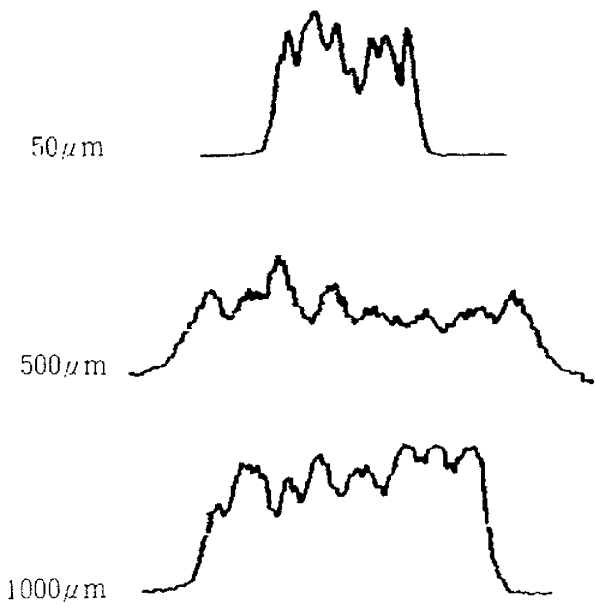

図 3 レーザー光束内のエネルギー分布 均質なエネルギー分布を示すパーフォー カルシステムを採用。

照射前

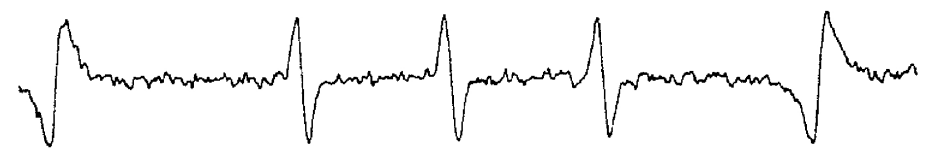

照射後

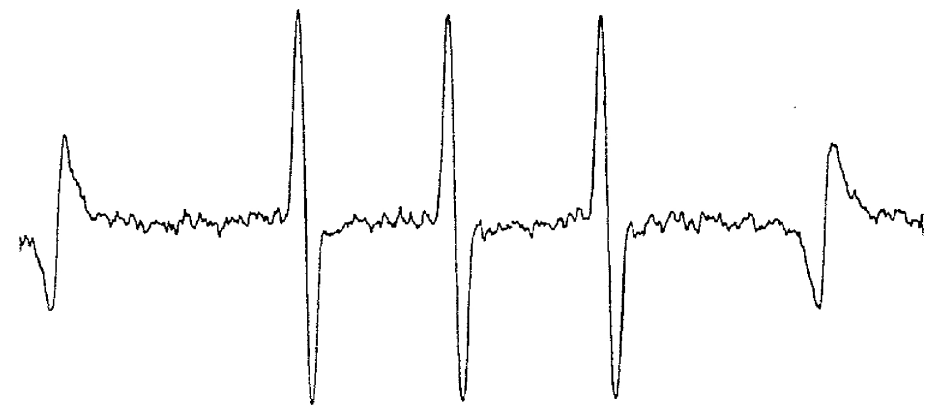

図 4 電子スピン共鳴法 (ESR) による一重項酸素の検出

2, 2，6，6-tetramethyl-4-piperidone hydrochloride (TMP) をトラッブ剂としたESR スペクトル。照射直後から 3 本のピークを持つ一重項酸素に基づくESRスペクトルが検出。

か、またよ゙のような活性酸素種が発生しているかを電子 スビン共鳴法を用い，半定量的に検索した。その結果，

一重項酸素、スーパーオキサイド，水酸化ラジカルなど の各種活性酸素の波形が明瞭に娭出された(図4，5)。 そのゆで、特に殺細胞作用の主体之されれている一重項酸 素が効率良く発生している事が明らかとなった。

\section{\# 3. 正常眼での光化学療法の効果}

正常有色家象10眼・マカク属サル9眼に対し合計108 万

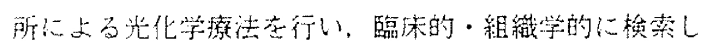
た。適正な棸件設定の下では，脈絡膜浅層の血管の選択 的閉塞が観察されたが、網膜感覚上皮はほぼ正常構造を 保持していた。一方，100mg/ $\mathrm{kg}$ の大量のNPe 6 を投与 後，通常の蛍光灯の下で飼育したものでもレーザーを照 射しなければ絧脈絡膜に異常は観察されなかった。

\# 4. 実験的脈絡膜新生血管の選択的治療

アカク属サル7眼に脈絡膜新生伹管を作製し、台計 18 力所に光化学療法老行った。NPe 6 投与量・レー ザ一照射强度は上記の対照実験の結果，及びNPe 6 の

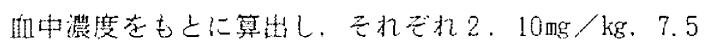
一225J / chよした。その結果, 条件設定を適正にする 事で，感覚䍃膜・脈絡毛細管板を障㸷せず，脈絡膜新生 侐管老閉塞しうる事が臨床的。組織学的に明らかよなっ 
照射直後

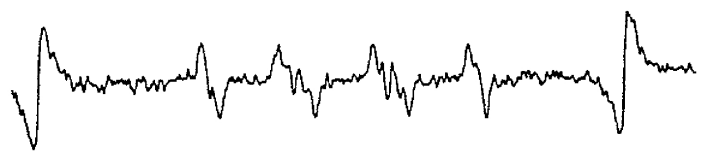

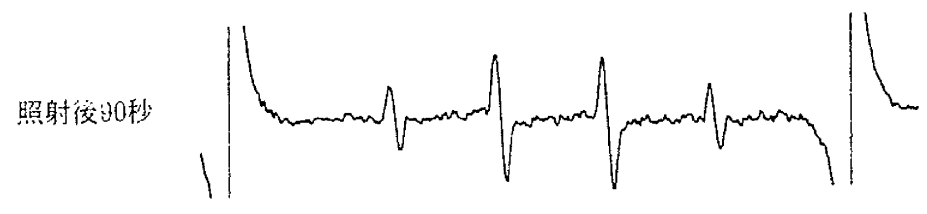

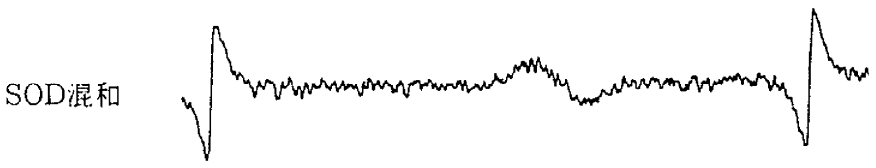

图 5 5，5-dimethyl-1-pyrroline-N-oxide（DMPO）をトラップ剖としたESRスペクトル 照射直後 (上段)にはスーパーオキサイド、照射後90秒（中段）を経過するとOHラジカ ルアダクトのESRスペクトルが検出。superoxide dismutase（SOD）を混和した場合 (下段), 中央にSOD由来の $\mathrm{Cu}^{2+}$ のシグナルのみ㭘出され，他の波形は消失。

た。

以上の基礎実験から, NPe 6 と664nm半導体レー ザーを用いた光化学㙩法では, 効率良く各種活性酸素を 発生させる事により，脈絡膜新生血管を選択的に，かつ 安全に閉塞させうる事が証明されたここれらの結果から， 近い将来の臨床応用の可能性が示唂されたが，動物実験 の結果を七トに応用する場合に, 特に照明条件, 投与濃 度が問題となる。脈絡膜新生血管を治療する場合には, 網膜血管を閉塞させない安全域の設定が重要である。こ の点に関し，我々は循環血繁中の濃度よレーザ一照射強 度を乗じたものをPDT index（mg/ml・ $\mathrm{J} / \mathrm{cm}^{2}$ ) とし， その安全域を正常サル眼での㬰禹結果, 及び脈絡膜新生 血管での実験結果から算出した。その結果，双方とも安 全域はほぼ一致しており，再現性は高い事が示された。 従って，絧膜血管内皮細胞のフリーラジカルに対する耐 性に関し，種差があるかもしれないが，基本的にはPDT indexは臨床応用を交全に行う上で役立つもの上考え的 れる。

\section{III その他の眼科疾患での光化学療法の応用 の可能性}

第 2 の光化学滰法の適応疾患之して, 網脈絡膜要性腫 㵑が挙げられる。その代表よして脈絡膜要性黑色腫がす る。放置すれば生命に関わる重篤な祑患であるため，眼 球摘出または近赤外の波長を有する半檪体レーザーでの
治療が行われている。レーザーでの治療は視機能を保全 できるので望ましい治㞠法であるが，一方，凝固が不充 分である之再発し，生命を失うことにもなる。完壁な腫

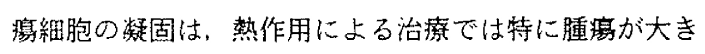
く愿い場合に限界がある。腫煌細胞を光化学作用を利用 して治療する試みは，すでに網膜芽細胞腫でへマトポル フィリンを使用して行われたよの報告がある。しかし， 長く光化学作用が残存するため, 患者を絶対暗室に一週 間以上置いておく必要が古り，不都合が多く一般に臨床 応用されなかった。 NPe 6 と可視光半導体レーザーに 上る治療が可能であれば眼科領域での悪性腫瘍の治療に 威力を発揮することが期待される。

\section{文 献}

1. Kahn HA, Moorhead HB : Statistics on blindness in the model reporting area, 1969-1970, Department of Health, Education, and Welfare publication no. (NIH), 73-427, US Government Printing Office, 1973.

2. Ryan SJ : Retina vol. II, 175-200, CV Mosby Co, 1989.

3. de Juan E Jr, Machemer R : Vitreous surgery for hemorrhagic and fibrous complications of age-related macular degeneration. Am J Opht halmol $105: 25-29,1988$. 
4. Schachat AP : Should we recommend vitreo us surgery for patients with choroidal neovascularization? Arch Ophthalmol 112:459-461, 1994.

5. Manyak MJ, Russo A, Smith PD, et al : Photodynamic therapy. J Clin Oncol $6: 380-391,1988$.

6. Roberts WG, Hasan $\mathrm{T}$ : Role of neovasculature andvascular permeability on the tumor retention of photodynamic agents. Cancer Res 52 : $924-930,1992$.

7. Thomas EL, Langhofer M : Closure of experimental subretinal neovascular vessels with dihematoporphyrin ether augmented argon green laser photocoagulation. Photochem Photobiol $46: 881-886,1987$.

8. Dougherty TJ, Kaufmann J, Goldfarb A, et al. : Photoradiation therapy for the treament of malignant tumors. Cancer Res 38 : 2628-2635. 1978.

9. Dougherty TJ : Photoradiation therapy (PRT) of malignant tumors. CRC Crit Rev 2 : 83-116. 1984.

10. Miller JW, Walsh AW, Kramer M, et al : Photodynamic therapy of experimental choroidal neovascularization using lipoprotein-delivered benzoporphyrin. Arch Ophthalmol $113: 810-818$, 1995.

11. Panagopoulos JA, Svitra PD, Puliafito CA, et al : Photodynamic therapy for experimental in trao cular melanoma using chloroalminum sulfonated phthalocyanine. Arch Ophthalmol 107 : 886-890, 1989.

12. Weishaupt KR, Gomer CJ, Dougherty TJ : Identification of singlet oxygen as the cytotoxic agent in photoinactivation of a murine tumor. Cancer Res 36 : 2326-2329, 1976.

13. Grossweiner LI : The science of phototherapy. 27-49. 150-151, CRC Press, Boca Raton, 1994.

14. Spinelli $\mathrm{P}$ : Photodynamic therapy and biomedical lasers. 526-530, Elsevier Science Publishers, Amsterdam, 1992.

15. Roberts WG, Shiau F-Y, Nelson JS, et al : In vitro characterization of monoaspertyl chlorin e6 and diaspertyl chlorin e6 for photodynamic therapy. J Natl Cancer Inst $80: 330-336,1988$.

16. 森圭介, 米谷新：水溶性光感受性物質NPe 6 を用
いた光化学療法の眼科応用の可能性. 第17回日本 レーザー医学会大会大会論文集. 83-86, 1996.

17. Mori K, Ohta T, Katagiri A, et al : Photodynamic therapy (PDT) with combination of a new sensitizer : NPe6 and a diode laser emitting at $664 \mathrm{~nm}$. Invest Ophthalmol Vis Sci 37 : 695 (suppl), 1996.

18. Mori K, Katagiri A, Sano A, et al : Photodynamic therapy for choroidal neovascularization with a hydrophilic sensitizer : NPe6. Invest Oph thalmol Vis Sci $38: 93$ (suppl), 1997.

19. Ohnishi Y, Yamana Y, Minei M : Phtoradiation therapy using argon laser and a hematoporphyrin derivative for retinoblastoma. A preliminary report. Jpn J Ophthalmol 30:409-419, 1986. 